\title{
Metal Pollution as a Causal Agent for Genetic Variation Based on Transplanted Centella asiatica Populations
}

\author{
Ong Ghim Hock, Wong Ling Shing and Geetha Subramaniam
}

\begin{abstract}
This study was to determine the relationships between genetic variation and metal concentrations based on polluted and clean populations of Centella asiatica from the transplantation study through the use of Random Amplified Microsatellites (RAMs). The 19 primers amplified a total of 153 reproducible bands across the 8 populations of $C$. asiatica used for a transplantation study at week 3 and week 6. For the transplantation study under laboratory conditions, there was a similar relationship found between the genetic variations and the metal accumulations. This indicated that the roots, leaves and stems of $C$. asiatica were able to reflect the metals pollution of the sampling sites.
\end{abstract}

Keywords - Metal pollution, Genetic variations, RAMs, Centella asiatica

\section{Introduction}

The presence of heavy metal in high concentration is a serious risk to ecology, which may lead to the deterioration of the quality the environment, and provoke humans' health problems. The heavy metal pollution in soil is a major threat due to their persistence, toxicity, long half-lives and the potential of bioaccumulation [1]. The industrialization leads to the wide spread of heavy metals, which the uptake of these pollutants by consumable medicinal plants has become a worldwide concern, as these contaminants may be transferred to human through the food chain [2]. One of the widely taken medicinal plant in Asian countries [3] is Centella asiatica (family: Umbelliferae), and it is listed in the WHO [4] as a useful medicinal plant.

The toxic effects of trace metals in different plants may also varies significantly [5]. The effects of trace metals on plant genetic variations have not yet been reported in the literature; therefore, it will be interesting to find out the relationships of trace metals and the changes in plant genetic structure. In this study, the RAMs technique (Randomly Amplified Microsatellites) was used to type genetic markers from very small amounts of DNA.

Ong Ghim Hock, Wong Ling Shing \& Geetha Subramaniam

Faculty of Health \& Life Sciences

INTI International University, Malaysia
In this study, the relationships between genetic variations and metal concentrations on polluted and clean populations of $C$. asiatica were determined, through Random Amplified Microsatellites (RAMs) markers.

\section{Methodology}

\section{A. Site Selection and Transplantation Study}

Four sites were selected namely UPM, Balakong, Seri Kembangan (SK) and Juru for the experimental study. UPM was selected because it is an agricultural area whereas Balakong, SK and Juru are known as industrial areas. The transplantation studies were carried out under laboratory conditions. Prior to transplantation, top soils from UPM, Balakong, SK and Juru were collected and placed into trays. The plants were transplanted after 3 weeks because an obvious effect could only be observed after 2 weeks of transplantation [6]. After the transplantation study, the samples were separated into leaves, stems and roots. The plant and soil samples were dried in an oven for 72 hours at $60{ }^{\circ} \mathrm{C}$ to obtain constant dry weights and determined for metals concentration.

\section{B. Metal Concentration Analysis}

For the determination of $\mathrm{Al}, \mathrm{As}, \mathrm{Ba}, \mathrm{Br}, \mathrm{Ca}, \mathrm{Ce}, \mathrm{Co}, \mathrm{Cr}$, Cs, Dy, Eu, Fe, Ga, Hf, K, La, Lu, Mg, Mn, Na, Ni, Rb, Sb, $\mathrm{Sc}, \mathrm{Sm}, \mathrm{Ta}, \mathrm{Tb}, \mathrm{Th}, \mathrm{Ti}, \mathrm{U}, \mathrm{V}, \mathrm{Yb}$ and $\mathrm{Zr}$, instrumental neutron activation analysis (INAA) was used in the TRIGA MARK II reactor at the Agensi Nuklear Malaysia (NUKLEAR MALAYSIA), Bangi, Selangor (Malaysia) [7, 8]. For $\mathrm{Cd}, \mathrm{Cu}, \mathrm{Ni}$ and $\mathrm{Pb}$, atomic absorption spectroscopy (AAS) was utilized [9].

\section{Genetic Variation Study}

DNA was isolated from the homogenized leaves by disrupting the cells in Edward's Solution. The modified extraction method was performed according to the protocol described by Barker et al. [10]. The primers selected in this study were obtained from Pasqualone et al. [11], Leroy [12], Lalhruaitluanga \& Prasad [13], Baloch et al. [14] and Lee et al. [15]. PCR was performed according to the Fermentas Life Sciences protocol. PCR Amplified products was separated by electrophoresis on a $2 \%$ agarose gel. Ethidium bromide staining was conducted to detect the bands on the agarose gel. 
Proc. of the Seventh International Conference On Advances in Applied Science and Environmental Engineering - ASEE 2017. Copyright (C) Institute of Research Engineers and Doctors. All rights reserved.

ISBN: 978-1-63248-125-2 doi: 10.15224/ 978-1-63248-125-2-01

For RAMs data, the amplified bands were scored for all individuals by using the UVIDoc software. The Software POPGENE version 1.31 [16] was used for the calculations of the number and percentage of polymorphic loci. To illustrate the relationship among populations, a dendrogram was constructed.

\section{Results and discussion}

Of the 43 primers tested, 19 primers (Table 1) which produced clear and distinct banding patterns were selected for the screening of polymorphisms in the populations of $C$. asiatica used in the transplantation study. Those primers amplified bands ranging in molecular weights from $100 \mathrm{bp}$ to $700 \mathrm{bp}$. The 19 primers amplified a total of 153 reproducible bands across the 8 populations of $C$. asiatica used in transplantation study at week 3 and week 6 .

Table 1 The primers code and their sequences that were used in the RAMs study

\begin{tabular}{|c|c|c|c|}
\hline No & $\begin{array}{l}\text { primer } \\
\text { code }\end{array}$ & Sequence & $\begin{array}{c}\text { Annealing } \\
\text { Temperature }{ }^{\circ} \mathrm{C}\end{array}$ \\
\hline 1 & UBC 807 & $\begin{array}{l}\text { 5' AGA GAG AGA } \\
\text { GAG AGA GT 3' }\end{array}$ & 54.8 \\
\hline 2 & UBC 822 & $\begin{array}{l}5, \text { TCT СТC ТCT } \\
\text { СТC ТCT CA } 3,\end{array}$ & 54.8 \\
\hline 3 & UBC 810 & 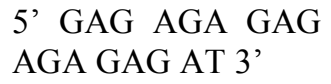 & 54.8 \\
\hline 4 & UBC 825 & $\begin{array}{l}5, \text { ACA CAC ACA } \\
\text { CAC ACA CT } 3 \text {, }\end{array}$ & 54.8 \\
\hline 5 & UBC 811 & $\begin{array}{l}\text { 5' GAG AGA GAG } \\
\text { AGA GAG AC 3' }\end{array}$ & 57.2 \\
\hline 6 & UBC 808 & $\begin{array}{l}\text { 5' AGA GAG AGA } \\
\text { GAG AGA GC 3, }\end{array}$ & 57.2 \\
\hline 7 & UBC 840 & $\begin{array}{l}\text { 5' GAG AGA GAG } \\
\text { AGA GAG AYT3' }\end{array}$ & 56.5 \\
\hline 8 & UBC 856 & $\begin{array}{l}\text { 5' ACA CAC ACA } \\
\text { CAC ACA CYA 3' }\end{array}$ & 56.5 \\
\hline 9 & UBC873 & $\begin{array}{l}\text { 5' GAT AGA TAG } \\
\text { ATA GAT A 3, }\end{array}$ & 43.9 \\
\hline 10 & NSSR 3 & $\begin{array}{l}\text { 5' CAG CAG CAG } \\
\text { CAG CAG 3' }\end{array}$ & 58.9 \\
\hline 11 & UBC 857 & $\begin{array}{l}5^{\prime} \text { ACA CAC ACA } \\
\text { CAC ACA CYG } 3 \text {, }\end{array}$ & 58.8 \\
\hline 12 & UBC 843 & $\begin{array}{l}5^{\prime} \text { CTC TCT CTC } \\
\text { TCT CTC TRC 3' }\end{array}$ & 58.8 \\
\hline 13 & UBC 818 & $\begin{array}{l}5^{\prime} \text { CAC ACA CAC } \\
\text { ACA CAC AG 3' }\end{array}$ & 57.2 \\
\hline 14 & UBC 820 & $\begin{array}{l}\text { 5' GTG TGT GTG } \\
\text { TGT GTG TC } 3,\end{array}$ & 57.2 \\
\hline 15 & UBC 827 & $\begin{array}{l}\text { 5' ACA CAC ACA } \\
\text { CAC ACA CG 3, }\end{array}$ & 57.2 \\
\hline 16 & ISSR 15 & $\begin{array}{l}\text { 5' CCC GTC } \text { TGT } \\
\text { GTG TGT 3', }\end{array}$ & 56.2 \\
\hline 17 & ISSR 19 & $\begin{array}{l}\text { 5' GGA GTC GTC } \\
\text { GTC GTC 3' }\end{array}$ & 58.9 \\
\hline 18 & ISSR 02 & $\begin{array}{l}\text { 5' GAC AGA CAG } \\
\text { ACA GAC 3' }\end{array}$ & 54.2 \\
\hline 19 & UBC 817 & $\begin{array}{l}\text { 5' CAC ACA CAC } \\
\text { ACA CAC AA 3, }\end{array}$ & 54.8 \\
\hline
\end{tabular}

In the clustering analysis for the transplantation study under laboratory conditions, the cluster divided the populations into two major groups (Figure 1). UPM week 3 and UPM week 6 were grouped in a major cluster, whereas Juru week 3, Juru week 6, Balakong week 3, Balakong week 6 , SK week 3 and SK week 6 were grouped in another major cluster. The clustered sites showing the how close the metal concentration present in the all parts of $C$. asiatica.

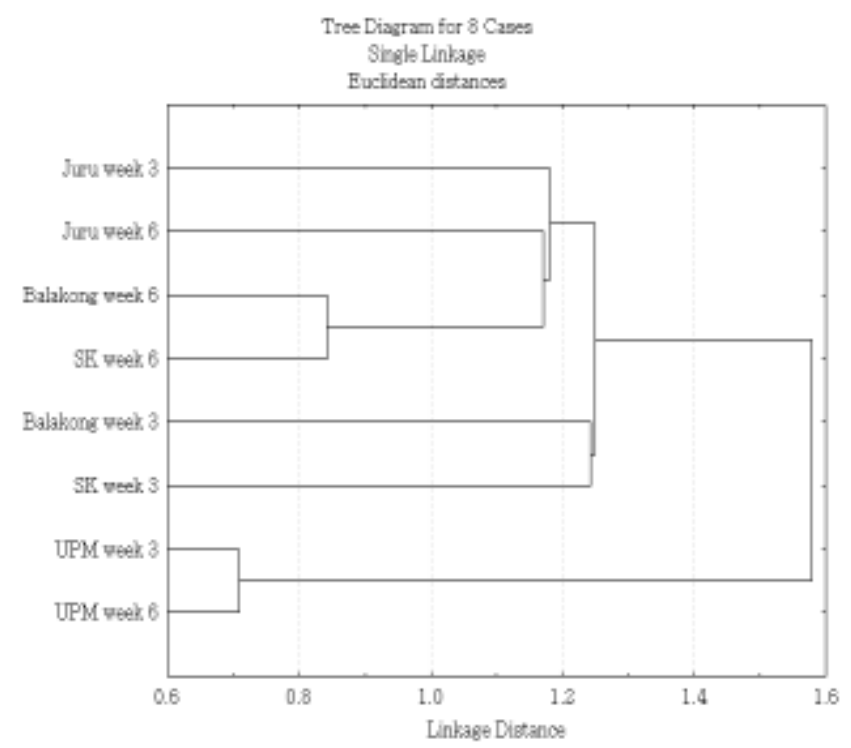

Figure 1 Hierarchical cluster analysis of C. asiatica based on 37 trace metals concentrations $\left(\log _{10}\right.$ mean+1) in all parts for the laboratory transplantation study.

The UPGMA dendrograms generated based on the distances derived from Dice similarity coefficients showed the highest distance value was between Juru week 3 and UPM week 6 for transplantation laboratory transplantation study (Figure 2 ). The cluster analysis generated based on all metal accumulations showed the greatest distance between UPM week 3 and Juru week 3 and UPM week 6 with Juru week 3.

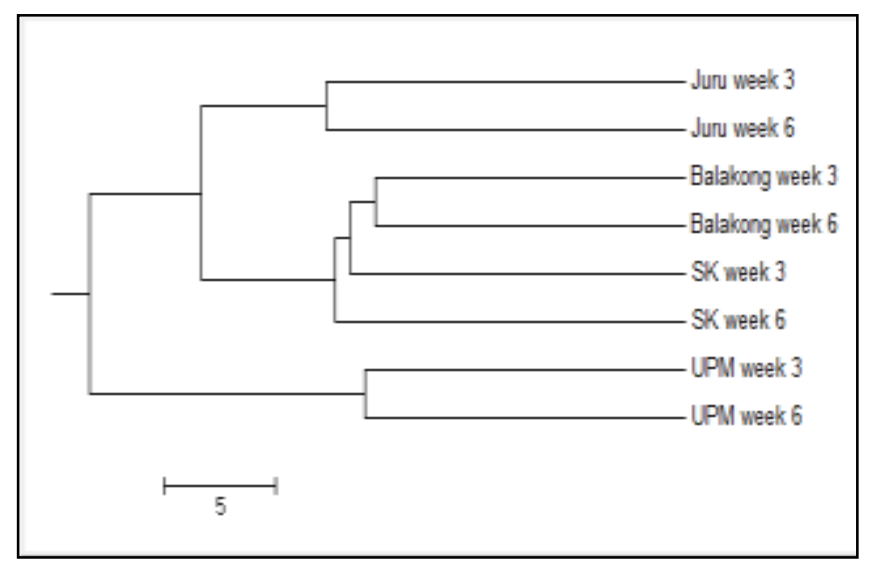

Figure 2 UPGMA dendrogram generated based on distances derived from the Dice similarity coefficients for $C$. asiatica population used in the laboratory transplantation study

For the laboratory transplantation study, the results showed a correlation of metal accumulations and genetic variations in $C$. asiatica. This indicated that the roots, leaves and stems were able to reflect the metal pollution of the 
sampling sites. The positive results based on the experimental studies under laboratory conditions revealed that metal accumulations affected the genetic variations in C. asiatica.

\section{Conclusion}

The 19 primers amplified a total of 153 reproducible bands across the 8 populations of $C$. asiatica used for a transplantation study at week 3 and week 6 . For the transplantation study under laboratory conditions, there was a similar relationship found between the genetic variations and the metal accumulations. This indicated that the roots, leaves and stems of $C$. asiatica were able to reflect the metals pollution of the sampling sites.

\section{Acknowledgment}

The authors wish to acknowledge the financial support provided through Fundamental Research Grant Scheme (FRGS) [Vote no. 5524631] by the Ministry of Higher Education Malaysia.

\section{References}

[1] Z. Ali, R. Malik, Z. Shinwari, and A. Qadir, "Enrichment, risk assessment, and statistical apportionment of heavy metals in tanneryaffected areas," International Journal of Environmental Science and Technology. 12(2): 537-550, 2015.

[2] S. Dubey, M. Shri, P. Misra, D. Lakhwani, S. K. Bag, M. F. Asif, P. K. Trivedi, R. D. Tripathi, and D. Chakrabarty, "Heavy metals induce oxidative stress and genome-wide modulation in transcriptome of rice root," Funct. Integr. Genomics, vol. 14, pp. 401-417, 2014.

[3] M. K. Zainol, A. A. Hamid, S. Yusof, S. Muse, "Antioxidant activity and total phenolic compounds of leaf, roots and petiotle of four accessions of Centella asiatica (L.) Urban," Food Chem 67:456-466, 2003

[4] WHO. Monographs on selected medicinal plants. Geneva: World Health Organization, 1, 77-85, 1999.

[5] A. M. León, J. M. Palma, F. J. Corpas, M. Gómez, M. C. RomeroPuertas, D. Chatterjee, R. M. Mateos, L. A. del Rio, and L. M. Sandalio, "Antioxidative enzymes in cultivars of pepper plants with different sensitivity to cadmium," Plant Physiol Biochem 40:813$820,2002$.

[6] U.S. Environmental Protection Agency, Ecological effects test guidelines (Public draft), EPA 712-C-96-163. Washington, DC, 1996.

[7] International Atomic Energy Agency (IAEA), Collection and preparation of bottom sediment samples for analysis of radionuclides and trace elements, IAEA-TECDOC-1360. Vienna: IAEA, 2003

[8] USEPA, Methods for collection, storage and manipulation of sediments for chemical and toxicology. Office of Water. U.S. Environmental Protection Agency. Washington, DC. EPA-823-B-01002, 2001

[9] G. H. Ong, L. S. Wong, A. L. Tan, and C. K. Yap, "Effects of metalcontaminated soils on the accumulation of heavy metals in gotu kola (Centella asiatica) and the potential health risks: a study in Peninsular Malaysia," Environmental monitoring and assessment. 188 (1): 1-10, 2016.

[10] C. S. Barker, L. Medrano-Gonzalez, J. Calambokidis, A. Perry, F. Pichler, H. Rosenbaum, J. M. Straley, J. Urrban-Ramirez, M. Yamaguchi, and O. von Ziegesar, "Population structure of nuclear and mitochondrial DNA variation among humpback whales in the Notrh Pacific," Mol Ecol 7:695-707, 1998.

[11] A. Pasqualone, C. Lotti, and A. Blanco, "Identification of durum wheat cultivars and monovarietal semolinas by analysis of DNA microsatellites," European Food Res Technol 210:144-147, 1999.
[12] X. J. Leroy, "Plant genomic instability detected by microsatelliteprimers," Electron J Biotechn 3:5-10, 2000.

[13] H. Lalhruaitluanga, and M. N. V. Prasad, "Comparative results of RAPD and ISSR markers for genetic diversity assessment in Melocanna baccifera Roxb. growing in Mizoram State of India." African J Biotechnol 8(22):6053-6062, 2009.

[14] F. S. Baloch, C. Kurt, H. Arioğlu, and H. Özkan, "Assaying of diversity among soybean (Glycin max (L.) Merr.) and peanut (Arachis hypogaea L.) genotypes at DNA level," Turkish J Agric For 34:285-301, 2010.

[15] J. W. Lee, Y.C. Kim, I. H. Jo, A. Y. Seo, J. H. Lee, O. T. Kim , D. Y. Hyun, S. W. Cha, K. H. Bang, and J. H. Cho, "Development of an ISSR-derived SCAR marker in Korean ginseng cultivars (Panax ginseng C.A. Meyer)". J Ginseng Res 35(1):52-59, 2011.

[16] F. C. Yeh, R. C. Yang, T. B. J. Boyle, Z. H. Ye, and J. X. Mao, POPGENE, The User Friendly Software for Population Genetic Analysis. Molecular Biology and Biotechnology Center, University of Alberta, Canada, 1997. 